\title{
CORPUS LUTEUM FUNCTION IN THE GUINEA-PIG;
}

\section{ARTERIAL AND LUTEAL PROGESTERONE LEVELS, AND THE EFFECTS OF HYSTERECTOMY AND HYPOPHYSECTOMY}

\author{
R. B. HEAP, J. S. PERRY AND I. W. ROWLANDS \\ A.R.C. Institute of Animal Physiology, Babraham, Cambridge, and \\ Wellcome Institute of Comparative Physiology, Regent's Park, London, N.W.1
}

(Received 25th October 1966)

Summary. In intact guinea-pigs the concentration of progesterone in luteal tissue rose and fell in a pattern similar to that of the volume of the corpus luteum, which in pregnancy grew to nearly twice the average size attained in the normal cycle. The concentration of progesterone in arterial plasma remained low throughout the normal cycle, but in pregnancy it increased at least ten-fold.

After hysterectomy, when the corpora lutea persisted for a long time and were comparable in size and in progesterone content to those of pregnancy, the levels in arterial plasma were very low, and were no higher than in the normal cycle.

After hypophysectomy early in the normal cycle, about one-half of the corpora lutea persisted for at least 5 weeks, were histologically normal in appearance and eventually reached a volume similar to that of corpora lutea in the normal cycle. If the operation was performed later, luteal regression was not delayed. The concentration of progesterone in the luteal tissue was again comparable to that found in pregnancy, whereas arterial levels remained extremely low, as after hysterectomy.

After hypophysectomy of mated animals, implantation was not affected, and a high proportion of embryos survived if the operation had been performed 2 or 3 days after ovulation, the size and histological appearance of the corpora lutea being similar to those of intact females at corresponding times in pregnancy. The arterial concentration was only comparable to that of normal pregnancy in animals in which apparently normal conceptuses survived.

After hysterectomy at different times after hypophysectomy, the corpora lutea in some animals increased to a size comparable with that in pregnancy, but in others there was little change. Plasma progesterone levels were low.

In general the concentration of progesterone in luteal tissue was closely related to the size of the corpora lutea except in the instance of 
the corpora lutea formed at the post-partum oestrus. Arterial progesterone levels, on the other hand, were high only in pregnant animals with healthy embryos, whether they were intact or hypophysectomized.

\section{INTRODUCTION}

The experiments described in this paper were designed to gain some further information about luteal activity in the guinea-pig, with special emphasis on the synthesis and secretion of progesterone by the corpus luteum. The concentration of progesterone in circulating plasma and in the corpus luteum was estimated during different phases of the reproductive cycle, after hysterectomy and after hypophysectomy. The work is an extension of previous studies on the growth and regression of the corpus luteum in the normal cycle and in pregnancy (Rowlands, 1956), after hysterectomy (Rowlands, 1962) and after hypophysectomy (Perry \& Rowlands, 1962). In the oestrous cycle, which lasts about 16 days, the corpus luteum grows to a volume of $2 \mathrm{~mm}^{3}$ by the 9 th to 1 Ith day after ovulation and then regresses. During pregnancy it grows until about the 20th day to a maximum volume of about $3 \mathrm{~mm}^{3}$ and maintains its size until after parturition, which occurs 65 to 70 days after ovulation. When hysterectomy is performed before the 11th day after ovulation the corpus luteum persists for at least 50 days after the operation (see Loeb, 1932, who gives other references) and its growth and progesterone content are similar to those in pregnancy (Rowlands \& Short, 1959). After hypophysectomy early in the normal cycle the corpus luteum persists (Dempsey, 1937; Rosenbusch-Weihs \& Ponse, 1957) and preliminary findings concerning its subsequent growth and progesterone content have been reported (Perry \& Rowlands, 1962; Heap, Perry \& Rowlands, 1965).

\section{MATERIALS AND METHODS}

\section{Animals}

The animals used were albino guinea-pigs of the M.R.C. strain. They were sexually mature, mainly nulliparous females (400 to $750 \mathrm{~g}$ ) maintained on a diet of SG1, green food and hay. The occurrence of regular oestrous cycles was checked before an experiment by daily observation for vaginal opening; the oestrous cycle, or pregnancy, was dated from the day after the vagina was fully open or the day a vaginal plug was found (Day 0).

\section{Surgical procedures}

Anaesthesia was induced with tribromoethanol ('Avertin', Winthrop Laboratories, New York, i.p., $2.5 \%$ in $0.9 \% \mathrm{NaCl}$ ) and maintained by ether. Ovariectomy was performed by a double flank incision, hysterectomy by laparotomy in the ventral mid-line, and hypophysectomy by the parapharyngeal route (see Rowlands, 1962). Hypophysectomized animals survived well if kept at a temperature above $70^{\circ} \mathrm{F}$ and given a daily injection of cortisone acetate $(25 \mathrm{mg} /$ day $)$ for 3 days after the operation. The completeness of hypophysectomy was assessed by examination of the sella turcica at autopsy 
or by fixing and sectioning the hypothalamo-hypophysial region. The complete absence of vesicular ovarian follicles was another useful confirmation. Bodyweight fell during the 1st week after operation but was subsequently maintained or even increased slightly in some animals.

\section{Sampling}

Blood ( 5 to $8 \mathrm{ml}$ ) was collected under anaesthesia (see above) by puncture of the left ventricle after exposing the heart. Sodium oxalate was used as anticoagulant and plasma was separated by centrifugation and stored at $-20^{\circ} \mathrm{C}$ for progesterone assay. For histological examination organs were fixed in Bouin's fluid. For progesterone assay corpora lutea were dissected immediately from the ovary, weighed individually on a torsion balance and stored in absolute alcohol at $-20^{\circ} \mathrm{C}$. Ovarian residual tissue was treated similarly.

\section{Histology}

The ovaries were cut in $5 \mu$ sections and every tenth section was mounted and stained in haematoxylin and eosin. The volume of each corpus luteum was measured by the method previously described by Rowlands (1961) and the results expressed as the mean of three diameters $\left(d^{3}\right)$ multiplied by 0.524 $(\pi / 6)$. The vagina and uterine horns of some of the animals were cut and stained in the same way.

\section{Progesterone assay}

Progesterone was measured by a highly sensitive fluorescence assay (Heap, 1964; Heap \& Linzell, 1966). Plasma and luteal tissue were extracted by the methods of Short (1958) and Rowlands \& Short (1959), respectively. A tracer amount of $4-{ }^{14} \mathrm{C}$-progesterone (about $1 \mathrm{~m} \mu \mathrm{c}$ ) was added to each sample to check losses incurred in the procedure. Recovery ranged from 40 to $60 \%$ and each result was corrected for $100 \%$ recovery.

\section{RESULTS}

\section{Luteal progesterone}

INTACT NON-PREGNANT GUINEA-PIGS

The progesterone concentration and content of the corpora lutea in virgin and in lactating guinea-pigs are shown in Table 1 . There was relatively little variation within or between animals in the weight or the progesterone concentration of the corpora lutea during the first half of the oestrous cycle. Variation in these respects during the period of regression in the second half of the cycle was shown to be considerable. To examine this feature more closely, the corpora lutea collected on the 15th day were divided into two groups for assay, according to whether they weighed less or more than $1 \mathrm{mg}$. It may be calculated that whereas decrease in weight between the 9th and 15 th days was 50 to $75 \%$, progesterone concentration decreased by at least $85 \%$ and the content by at least $95 \%$, the corpora lutea which had regressed further in size containing relatively less progesterone. 
In lactating animals 12 to 13 days post partum, two sets of corpora lutea were distinguishable both histologically and in size; one set remaining from the preceding pregnancy and the other set being derived from the ovulation which occurs within a few hours after parturition in the guinea-pig. The progesterone concentration in the two sets was low and similar, but their content differed by a factor of four due to the much larger size of the corpora lutea formed at the post-partum ovulation, which in fact were larger than those of the normal cycle.

TABLE 1

PROGESTERONE LEVELS IN LUTEAL TISSUE IN NON-PREGNANT GUINEA-PIGS

\begin{tabular}{|c|c|c|c|c|c|}
\hline \multirow{2}{*}{ Days after ovulation } & \multirow{2}{*}{$\begin{array}{l}\text { No. of } \\
\text { animals }\end{array}$} & \multicolumn{2}{|c|}{ Corpora lutea } & \multicolumn{2}{|c|}{ Luteal progesterone } \\
\hline & & No. & $\begin{array}{l}\text { Average weight } \\
\qquad(m g)\end{array}$ & $\begin{array}{l}\text { Concn. } \\
\text { (ng/mg) }\end{array}$ & $\begin{array}{c}\text { Content } \\
\text { (ng/CL of average size) }\end{array}$ \\
\hline $\begin{array}{c}\text { Virgin } \\
5-6 \\
9 \\
15^{*} \\
15 \dagger\end{array}$ & $\begin{array}{l}5 \\
4 \\
5 \\
8\end{array}$ & $\begin{array}{r}14 \\
9 \\
16 \\
24\end{array}$ & $\begin{array}{l}2 \cdot 8 \\
2 \cdot 4 \\
1 \cdot 2 \\
0 \cdot 6\end{array}$ & $\begin{array}{l}8 \cdot 6 \\
7 \cdot 6 \\
1 \cdot 1 \\
0 \cdot 3\end{array}$ & $\begin{array}{c}24 \\
18 \\
1 \cdot 3 \\
0 \cdot 2\end{array}$ \\
\hline $\begin{array}{l}\text { Lactating, } 12-13 \text { days post partum } \\
\text { New GL } \\
\text { Old CLS }\end{array}$ & $\begin{array}{l}9 \\
9\end{array}$ & $\begin{array}{l}33 \\
31\end{array}$ & $\begin{array}{l}3.6 \\
1.5\end{array}$ & $\begin{array}{l}1 \cdot 1 \\
0.8\end{array}$ & $\begin{array}{l}4 \cdot 1 \\
1 \cdot 2\end{array}$ \\
\hline
\end{tabular}

Corpora lutea: * weighing more than $1 \mathrm{mg}$; $\dagger$ weighing less than $1 \mathrm{mg}$; $\ddagger$ derived from post-partum ovulation; $\$$ remaining from preceding pregnancy.

TABLE 2

CONCENTRATION OF PROGESTERONE IN ARTERIAL PLASMA IN NONPREGNANT GUINEA-PIGS

\begin{tabular}{c|c|c}
\hline Days after ovulation & No. of animals & $\begin{array}{c}\text { Plasma progesterone }(\mathrm{ng} / \mathrm{ml}) \\
\text { (Mean } \pm \text { S.E. })\end{array}$ \\
\hline Virgin & 9 & \\
$5-8$ & 9 & $9 \cdot 8 \pm 2 \cdot 5$ \\
$9-10$ & 4 & $9 \cdot 5 \pm 2 \cdot 8$ \\
$11-15$ & 6 & $3 \cdot 9 \pm 2 \cdot 1$ \\
Lactating, 11-15 days post partum & 6 & $3 \cdot 0 \pm 1 \cdot 0$ \\
Ovariectomized, pooled sample & $7 \cdot 7$ \\
\hline
\end{tabular}

\section{Plasma progesterone}

Table 2 shows that the arterial concentration of progesterone was low during the normal cycle. The observed values were higher during the period of luteal growth but they were not significantly different from those recorded during luteal regression, or in a pooled plasma sample taken 7 days after ovariectomy.

\section{Luteal progesterone}

\section{INTACT PREGNANT GUINEA-PIGS}

Table 3 shows that by the 20th day of pregnancy the corpora lutea had grown to about twice the average weight attained in the normal cycle of virgin 
animals (see Table 1). Their progesterone concentration had increased threefold and their average progesterone content was six times as great. Their size and progesterone concentration remained high throughout (see also Rowlands \& Short, 1959) and, on average, the corpus luteum of mid-pregnancy contained nearly eight times as much progesterone as that of the normal cycle.

\section{Plasma progesterone}

Comparison of the data given in Tables 2 and 3 shows that the plasma progesterone level on the 15th day of pregnancy was little different from that

TABLE 3

PROGESTERONE LEVELS IN LUTEAL TISSUE AND ARTERIAL PLASMA IN PREGNANT GUINEA-PIGS

\begin{tabular}{|c|c|c|c|c|c|c|}
\hline \multirow{2}{*}{$\begin{array}{l}\text { Days } \\
\text { preg- } \\
\text { nant }\end{array}$} & \multirow{2}{*}{$\begin{array}{l}\text { No. of } \\
\text { animals }\end{array}$} & \multicolumn{2}{|c|}{ Corpora lutea } & \multicolumn{2}{|c|}{ Luteal progesterone } & \multirow{2}{*}{$\begin{array}{c}\text { Plasma progesterone } \\
(\mathrm{ng} \mid \mathrm{ml})\end{array}$} \\
\hline & & No. & $\begin{array}{l}\text { Average weight } \\
\text { (mg) }\end{array}$ & $\begin{array}{c}\text { Concentration } \\
(n g / m g)\end{array}$ & $\begin{array}{c}\text { Content } \\
\text { (ng/CL of average size) }\end{array}$ & \\
\hline $\begin{array}{c}15 \\
20-22 \\
30-33 \\
50-54\end{array}$ & $\begin{array}{l}3 \\
4 \\
5 \\
4\end{array}$ & $\begin{array}{l}11 \\
15 \\
16 \\
14\end{array}$ & $\begin{array}{l}4 \cdot 6 \\
5 \cdot 2 \\
5 \cdot 2 \\
5 \cdot 9\end{array}$ & $\begin{array}{l}20 \cdot 6 \\
28 \cdot 8 \\
29 \cdot 9 \\
31 \cdot 3\end{array}$ & $\begin{array}{r}95 \\
152 \\
156 \\
183\end{array}$ & $\begin{array}{r}6.3 \\
113.6 \\
167.6 \\
149.6\end{array}$ \\
\hline
\end{tabular}

reached in the normal cycle. The rise in the arterial level to more than $100 \mathrm{ng} / \mathrm{ml}$ plasma was thus seen to occur a few days later than the rise in the luteal level. Whereas the luteal progesterone levels remained constant after the 20th day, the arterial level reached a peak about the 30th day of pregnancy.

\section{Luteal progesterone}

\section{HYSTERECTOMIZED GUINEA-PIGS}

Hysterectomy was performed 5 or 10 days after ovulation and the corpora lutea were collected 25, 30 or 60 days after ovulation (Table 4). In animals

TABLE 4

PROGESTERONE LEVELS IN LUTEAL TISSUE AND ARTERIAL PLASMA IN HYSTEREGTOMIZED GUINEA-PIGS

\begin{tabular}{|c|c|c|c|c|c|c|c|}
\hline \multicolumn{2}{|c|}{ No. of days between: } & \multirow{2}{*}{$\begin{array}{c}\text { No. } \\
\text { of } \\
\text { animals }\end{array}$} & \multicolumn{2}{|c|}{ Corpora lutea } & \multicolumn{2}{|c|}{ Luteal progesterone } & \multirow{2}{*}{$\begin{array}{c}\text { Plasma } \\
\text { progesterone } \\
(\mathrm{ng} / \mathrm{ml})\end{array}$} \\
\hline $\begin{array}{l}\text { Ovulation } \\
\text { and hyster- } \\
\text { ectomy }\end{array}$ & $\begin{array}{l}\text { Hyster- } \\
\text { ectomy and } \\
\text { sampling }\end{array}$ & & No. & $\begin{array}{c}\text { Average } \\
\text { weight } \\
(\mathrm{mg})\end{array}$ & $\begin{array}{c}\text { Concen- } \\
\text { tration } \\
(\text { ng/mg })\end{array}$ & $\begin{array}{c}\text { Content } \\
\text { (ng/CL of average size })\end{array}$ & \\
\hline $\begin{array}{r}5 \\
5 \\
5 \\
10 \\
10\end{array}$ & $\begin{array}{c}25 \\
30-42 \\
55 \\
15 \\
50\end{array}$ & $\begin{array}{l}3 \\
6 \\
3 \\
3 \\
3\end{array}$ & $\begin{array}{l}10 \\
- \\
11 \\
11 \\
6\end{array}$ & $\begin{array}{l}4 \cdot 9 \\
- \\
4 \cdot 8 \\
5 \cdot 6 \\
3 \cdot 3\end{array}$ & $\begin{array}{l}53 \cdot 1 \\
\overline{2} \cdot 6 \\
29 \cdot 2 \\
16 \cdot 9\end{array}$ & $\begin{array}{r}260 \\
- \\
144 \\
168 \\
56\end{array}$ & $\begin{array}{c}6 \cdot 6 \\
4 \cdot 7 \pm 1 \cdot 6 \\
2 \cdot 5 \\
3 \cdot 5 \\
4 \cdot 3\end{array}$ \\
\hline
\end{tabular}

hysterectomized early (5th day of the cycle) the corpora lutea reached a weight similar to those in pregnancy. Their progesterone concentration initially rose to a much higher level ( $53 \mathrm{ng} / \mathrm{mg}$ ), and later declined to the level found in the 


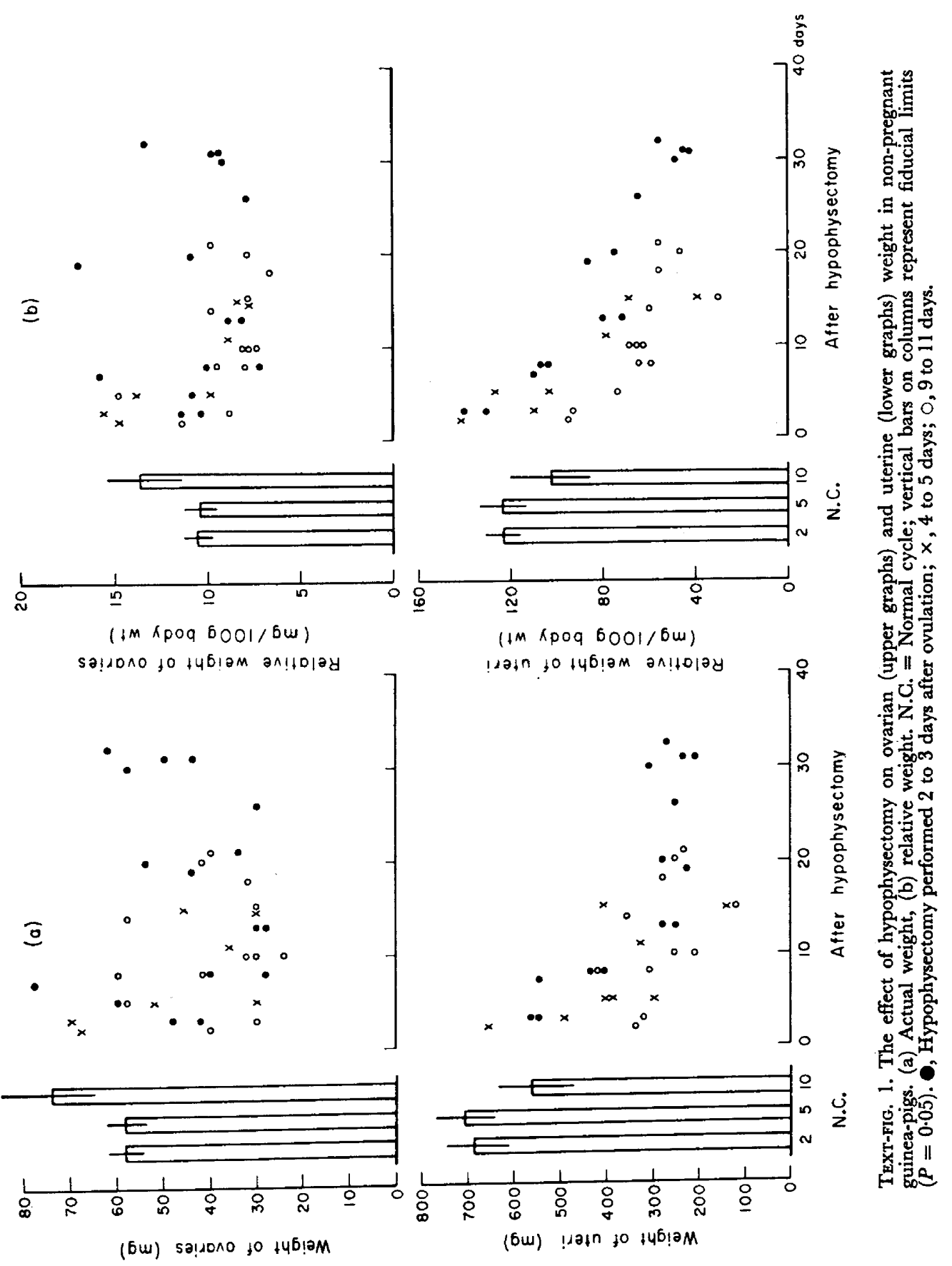


corpora lutea of pregnancy $(29 \mathrm{ng} / \mathrm{mg}$ ). When hysterectomy was performed on the 10th day after ovulation the luteal progesterone level rose to that found in corpora lutea of pregnancy and then decreased by one-half $(17 \mathrm{ng} / \mathrm{mg}$ ) after a period of 50 days.

\section{Plasma progesterone}

Table 4 also shows the arterial concentration of progesterone in four pooled samples of blood taken from the same hysterectomized animals (see above), together with that in a further six females analysed individually and for which the standard error has been calculated. It will be seen that there was very little progesterone in the plasma of these guinea-pigs, in contrast to the very high concentration in the corpora lutea. The blood levels were of the same order as those in the normal cycle and after ovariectomy (Table 2); the differences between the groups lay within the limits of the analytical error at these low values.

\section{HYPOPHYSECTOMIZED NON-PREGNANT GUINEA-PIGS}

\section{Effect on organ weights}

Text-fig. 1 shows the absolute and relative weight $(\mathrm{mg} / 100 \mathrm{~g}$ body-weight) of fixed ovaries and uteri of animals hypophysectomized between the 2nd and 11 th day after ovulation. The absolute weight of these organs declined rapidly after the operation; the relative weight of the ovary stabilized after about the 15th day after hypophysectomy but that of the uterus declined throughout the experimental period of about 3 weeks. Adrenal and thyroid weight fell approximately in proportion to the decline in body-weight.

The abrupt fall in ovarian weight in animals hypophysectomized at midcycle was related to the sudden disappearance of vesicular follicles; when the operation was performed earlier, before the post-ovulatory growth of follicles, the fall in ovarian weight was less marked. About 5 weeks after hypophysectomy the relative ovarian weight had fallen from about 12 to about $8 \mathrm{mg} / 100 \mathrm{~g}$ body-weight. In immature guinea-pigs the corresponding fall was from about 20 to about $6 \mathrm{mg} / 100 \mathrm{~g}$ body-weight (Perry \& Rowlands, 1963). This difference may be related to the persistence of corpora lutea in the ovaries of the present series.

\section{Number of corpora lutea}

Table 5 shows that the number of corpora lutea surviving after hypophysectomy declined steadily. A significant reduction had already occurred within a few days of the operation, and by 5 weeks afterwards only about onehalf remained. In the normal cycle (Table 5), up to 80 days after hysterectomy (Rowlands, 1962), and in pregnancy (Rowlands, 1956), the number of corpora lutea remained constant.

\section{Volume of corpora lutea}

Table 6 shows the effect of hypophysectomy at different times in the normal cycle on the volume of the corpus luteum. The results obtained in forty-four $\mathrm{F}^{*}$ 
guinea-pigs which were hypophysectomized on the 2nd or 3rd day after ovulation and examined at different periods thereafter, indicated that luteal growth was retarded to some extent but continued for a period of at least 30 days, when the corpus luteum had attained a size equivalent to that on the 10th day

TABLE 5

NUMBERS OF CORPORA LUTEA AFTER HYPOPHYSEGTOMY

\begin{tabular}{|c|c|c|c|c|}
\hline \multirow{2}{*}{$\begin{array}{l}\text { Days after } \\
\text { ovulation }\end{array}$} & \multirow{2}{*}{$\begin{array}{c}\text { Days after } \\
\text { hypophysectomy }\end{array}$} & \multirow{2}{*}{$\begin{array}{l}\text { No. of } \\
\text { animals }\end{array}$} & \multicolumn{2}{|c|}{ No. of corpora lutea } \\
\hline & & & Mean \pm S.E. & $\begin{array}{l}\text { Fiducial limits } \\
(P=\mathbf{0 . 0 5})\end{array}$ \\
\hline $\begin{array}{c}\text { Normal cycle } \\
5 \\
10 \\
15\end{array}$ & - & $\begin{array}{l}6 \\
6 \\
6\end{array}$ & $\begin{array}{l}5 \cdot 33 \pm 0 \cdot 34 \\
4 \cdot 50 \pm 0 \cdot 14 \\
4 \cdot 83 \pm 0 \cdot 32\end{array}$ & $\begin{array}{l}4 \cdot 46-6 \cdot 20 \\
4 \cdot 14-4 \cdot 86 \\
4 \cdot 01-5 \cdot 65\end{array}$ \\
\hline $\begin{array}{l}\text { Hypophysectomy } \\
2 \text { to } 3\end{array}$ & $\begin{array}{c}2-5 \\
6-9 \\
10-15 \\
16-26 \\
27-32\end{array}$ & $\begin{array}{r}9 \\
13 \\
9 \\
10 \\
5\end{array}$ & $\begin{array}{l}3 \cdot 78 \pm 0.40 \\
3 \cdot 06 \pm 0.35 \\
3 \cdot 00 \pm 0 \cdot 24 \\
2 \cdot 50 \pm 0.43 \\
2 \cdot 40 \pm 0.55\end{array}$ & $\begin{array}{l}3 \cdot 00-4 \cdot 56 \\
2 \cdot 42-3 \cdot 70 \\
2 \cdot 22-3 \cdot 78 \\
1 \cdot 75-3 \cdot 25 \\
1 \cdot 76-3 \cdot 04\end{array}$ \\
\hline 4 to 8 & $\begin{array}{l}2-5 \\
6-30\end{array}$ & $\begin{array}{l}7 \\
6\end{array}$ & $\begin{array}{l}3.00 \pm 0.53 \\
3.66 \pm 0.49\end{array}$ & $\begin{array}{l}1 \cdot 70-4 \cdot 31 \\
2 \cdot 39-4.93\end{array}$ \\
\hline 9 to 11 & $\begin{array}{c}2-9 \\
10-21\end{array}$ & $\begin{array}{l}6 \\
8\end{array}$ & $\begin{array}{l}3.50 \pm 0.51 \\
2 \cdot 38 \pm 0.47\end{array}$ & $\begin{array}{l}2 \cdot 19-4 \cdot 81 \\
1 \cdot 28-3 \cdot 49\end{array}$ \\
\hline
\end{tabular}

TABLE 6

VOLUME OF CORPUS LUTEUM AFTER HYPOPHYSECTOMY

\begin{tabular}{|c|c|c|c|c|}
\hline \multirow{2}{*}{$\begin{array}{l}\text { Days after } \\
\text { ovulation }\end{array}$} & \multirow{2}{*}{$\begin{array}{c}\text { Days after } \\
\text { hypophysectomy }\end{array}$} & \multirow{2}{*}{$\begin{array}{l}\text { No. of } \\
\text { animals }\end{array}$} & \multicolumn{2}{|c|}{ Volume of corpus luteum $\left(\mathrm{mm}^{3}\right)$} \\
\hline & & & Mean $\pm S . E$ & $\begin{array}{l}\text { Fiducial limits } \\
(P=0.05)\end{array}$ \\
\hline $\begin{array}{c}\text { Normal cycle } \\
5 \\
10 \\
15\end{array}$ & $\bar{z}$ & $\begin{array}{l}6 \\
6 \\
6\end{array}$ & $\begin{array}{l}1 \cdot 52 \pm 0.05 \\
2 \cdot 00 \pm 0.05 \\
1 \cdot 06 \pm 0.04\end{array}$ & $\begin{array}{l}1 \cdot 38-1 \cdot 66 \\
1 \cdot 86-2 \cdot 14 \\
0 \cdot 96-1 \cdot 16\end{array}$ \\
\hline $\begin{array}{l}\text { Hypophysectomy } \\
2 \text { to } 3\end{array}$ & $\begin{array}{c}2-5 \\
6-9 \\
10-15 \\
16-26 \\
27-32 \\
>65\end{array}$ & $\begin{array}{r}8 \\
12 \\
9 \\
8 \\
4 \\
3\end{array}$ & $\begin{array}{l}1 \cdot 26 \pm 0.19 \\
1.49 \pm 0.12 \\
1 \cdot 82 \pm 0.12 \\
1.43 \pm 0.21 \\
2 \cdot 11 \pm 0.26 \\
0.46 \pm 0.08\end{array}$ & $\begin{array}{c}0.94-1.58 \\
1.23-1.75 \\
1.52-2.12 \\
1.11-1.72 \\
1.67-2.55 \\
-\end{array}$ \\
\hline 4 to 8 & $\begin{array}{l}2-5 \\
6-30\end{array}$ & $\begin{array}{l}6 \\
7\end{array}$ & $\begin{array}{l}1.68 \pm 0.17 \\
1.27 \pm 0.11\end{array}$ & $\begin{array}{l}1.32-2.04 \\
0.93-1.61\end{array}$ \\
\hline 9 to 11 & $\begin{array}{c}2-9 \\
10-21\end{array}$ & $\begin{array}{l}6 \\
7\end{array}$ & $\begin{array}{l}1.28 \pm 0.20 \\
0.72 \pm 0.25\end{array}$ & $\begin{array}{l}0.91-1.63 \\
0.38-1.06\end{array}$ \\
\hline
\end{tabular}

of the cycle in the intact guinea-pig. Neither the time at which luteal regression sets in nor the rate at which it occurs have been determined, but the retention of corpora lutea, albeit considerably regressed, in animals killed 68 days or more after hypophysectomy, shows that the normal process of luteolysis had 
been greatly retarded. In another group of thirteen guinea-pigs, hypophysectomized on the 4th to 8th days after ovulation, no significant changes occurred in the mean size of the corpora lutea during post-operative periods of up to 30 days. Luteal regression was observed, however, in the third group of animals (see Table 6) in which this operation was performed on the 9th to 11 th days after ovulation, i.e. when maximum development of the corpus luteum had already occurred, but even so the rate of regression was slower than in intact animals.

\section{Ovarian histology after hypophysectomy}

The morphological and histological effects of hypophysectomy on the follicular apparatus in immature guinea-pigs and in adults previously hysterectomized have already been described by Perry \& Rowlands (1963) and by Rowlands (1962) respectively. In the intact guinea-pig the vesicular follicles that remain after ovulation undergo rapid atresia, and it is not until about 5 days later that a new crop appears. After hypophysectomy in the mature guinea-pig it was found that follicular regression was well advanced by the 3rd day after the operation, and any follicles that developed later became atretic soon after the appearance of the antrum and were later resorbed into the ovarian stroma. In some instances the degeneration of larger follicles was associated with the formation of fluid-filled cysts lined by a single layer of cubical epithelium. The absence of normal vesicular follicles was, therefore, a useful criterion of the completeness of the operation.

The morphology of the corpus luteum during the growth which occurred after hypophysectomy performed before the 8th day was indistinguishable from that of the corpus luteum in the normal cycle. The outline of the luteal cell was so indistinct that it was not possible to make a reliable estimate of cell size. The luteal cells were loosely arranged, in comparison with the compact appearance of the corpus luteum of murine rodents. The nuclei were very prominent and mitotic figures were often seen, especially in the peripheral region of the gland.

The corpus luteum was found to remain well vascularized after hypophysectomy, as was shown by arterial injections of India ink in several animals. Particles were found in vessels surrounding the gland and in many of the lesser ones situated centrally, although, as far as could be determined, they were not distributed widely throughout the tissue.

In regressing corpora lutea there was a higher proportion of shrunken elliptical nuclei and of cytoplasmic vacuolation, and an increase in the epithelial connective tissue and in the closure of the blood vessels. Only one guinea-pig out of fifty-seven totally hypophysectomized before the 8th day after ovulation, provided clear histological evidence of luteal regression. There was little mucification of the vaginal epithelium in hypophysectomized guineapigs.

\section{Decidual reaction}

In six guinea-pigs the pituitary was removed on the 2nd day of the cycle and the uterine horns were traumatized by ligatures threaded loosely through 
the uterine wall 4 days later. No decidual reaction was visible when the uterus was examined macroscopically and histologically on the 12th day of the cycle. The mean relative weights of ovaries $(11.1 \pm 0.5 \mathrm{mg})$ and uterine horns $(92 \pm 10 \mathrm{mg})$ were not significantly different from those in hypophysectomized control guinea-pigs. It was found in subsequent experiments, however, that the incidence of the decidual response to traumatization by this method could be very variable in intact animals.

\section{Luteal progesterone}

The progesterone concentration of the luteal tissue and the progesterone content of a corpus luteum of average size were both considerably higher after

TABLE 7

PROGESTERONE LEVELS IN LUTEAL TISSUE IN NON-PREGNANT GUINEA-PIGS HYPOPHYSECTOMIZED 2 DAYS AFTER OVULATION

\begin{tabular}{c|c|c|c|c|c}
\hline $\begin{array}{c}\text { Days after } \\
\text { hypophysectomy }\end{array}$ & $\begin{array}{c}\text { No. of } \\
\text { animals }\end{array}$ & No. & $\begin{array}{c}\text { Corpora lutea } \\
\text { Average weight } \\
(\mathrm{mg})\end{array}$ & $\begin{array}{c}\text { Concentration } \\
(\mathrm{ng} / \mathrm{mg})\end{array}$ & $\begin{array}{c}\text { Content } \\
\text { (ng/CL of average size })\end{array}$ \\
\hline 5 & 12 & 44 & 2.6 & 32 & 82 \\
19 & 18 & 47 & 1.6 & 33 & 52 \\
\hline $\begin{array}{c}\text { Ovarian residue, } \\
\text { pooled sample }\end{array}$ & 30 & Total weight 833 & 0.2 & - \\
\hline
\end{tabular}

TABLE 8

PROGESTERONE LEVELS IN ARTERIAL PLASMA IN NON-PREGNANT GUINEA-PIGS HYPOPHYSECTOMIZED

2 DAYS AFTER OVULATION

\begin{tabular}{c|c|c}
\hline $\begin{array}{c}\text { Days after } \\
\text { hypophysectomy }\end{array}$ & $\begin{array}{c}\text { No. of } \\
\text { animals }\end{array}$ & $\begin{array}{c}\text { Plasma progesterone }(\mathrm{ng} / \mathrm{ml}) \\
(\text { Mean } \pm \text { S.E. })\end{array}$ \\
\hline 5 & 6 & $7 \cdot 0 \pm 1 \cdot 2$ \\
19 & 7 & $1 \cdot 5 \pm 0.3$ \\
$65-83$ & 4 & $8 \cdot 5 \pm 4 \cdot 1$ \\
\hline
\end{tabular}

hypophysectomy than in the normal cycle (compare Table 7 with Table 1). The high concentration in the luteal tissue of guinea-pigs hypophysectomized on the 2nd day of the cycle was very similar to that found in pregnancy and it remained at this high value from as early as 5 days after the operation to at least 14 days later. Since the rate of growth of the corpus luteum declined after the pituitary was removed, the progesterone content was only about one-half that found in pregnancy, when the gland was much larger. The low level of progesterone in ovarian residue confirmed the clean separation of luteal and stromal tissue.

\section{Plasma progesterone}

Table 8 shows that arterial progesterone levels after hypophysectomy were 
very low and were similar to those in the normal cycle and after hysterectomy. In all instances they were not significantly different from those in ovariectomized females.

\section{HYPOPHYSECTOMIZED PREGNANT GUINEA-PIGS}

The individual results for thirty-three guinea-pigs are shown in Table 9. The operation was performed on twenty-seven of these animals before the expected time of implantation (on Day 7) and from the observations made on the state of the uterus at death it may be deduced that the process of ovo-implantation had proceeded normally in at least twenty of them. Moreover, normal conceptuses ranging in number from one to six were found in sixteen of these twenty animals killed up to 28 days after the operation.

Hypophysectomy performed in the early post-implantation stage of pregnancy (Nos. 28, 29 and 30) did not apparently have an immediate effect on embryonic development as regressing embryos were found in two of them when killed 17 and 20 days later. Embryonic survival was nil in guinea-pigs hypophysectomized in the 5th to 7 th weeks (Nos. 31, 32 and 33).

The times of autopsy were selected to represent stages beyond the length of the normal cycle in most cases, and in those females in which arterial progesterone levels were measured, blood was taken at times corresponding to stages in pregnancy when placental progesterone secretion was very low (Heap \& Deanesly, 1966). When normal or regressing conceptuses were present in the uterus at the time of autopsy, the corpora lutea were comparable in size and in histological appearance to those of intact animals at corresponding times in pregnancy. Arterial progesterone levels, however, were only comparable with those of intact pregnant females (60 to $289 \mathrm{ng} / \mathrm{ml}$ plasma) when normal conceptuses were present. Normal corpora lutea were also found in animals that contained only regressing embryos but the plasma progesterone values were low (0 to $21 \mathrm{ng} / \mathrm{ml}$ plasma). An apparent exception with respect to the size of the corpora lutea was No. 10; the value given represents an average volume of three corpora lutea, one of normal size $\left(2 \cdot 14 \mathrm{~mm}^{3}\right)$ and two which were smaller and abnormal in histological appearance.

The data provide no evidence for a decline in the number of corpora lutea after hypophysectomy in pregnant animals (cf. Table 5) but they show that embryonic survival is affected. In twenty-one guinea-pigs of the same stock mated at the post-partum oestrus the average number of corpora lutea during the first 4 weeks of pregnancy was $5 \cdot 6$ and the average number of foetuses 4.2 of which 0.2 were regressing. In animals hypophysectomized on the 2nd or 3rd day after ovulation and killed after the time of implantation (Nos. 6 to 25 ) the corresponding figures were $4.5,3 \cdot 0$ and 0.7 respectively.

\section{THE EFFECT OF HYSTERECTOMY IN HYPOPHYSECTOMIZED GUINEA-PIGS}

Table 10 shows the numbers and volumes of corpora lutea, and plasma progesterone levels, in guinea-pigs hysterectomized at various intervals after hypophysectomy early in the normal cycle. They were killed 2 to 5 weeks after 


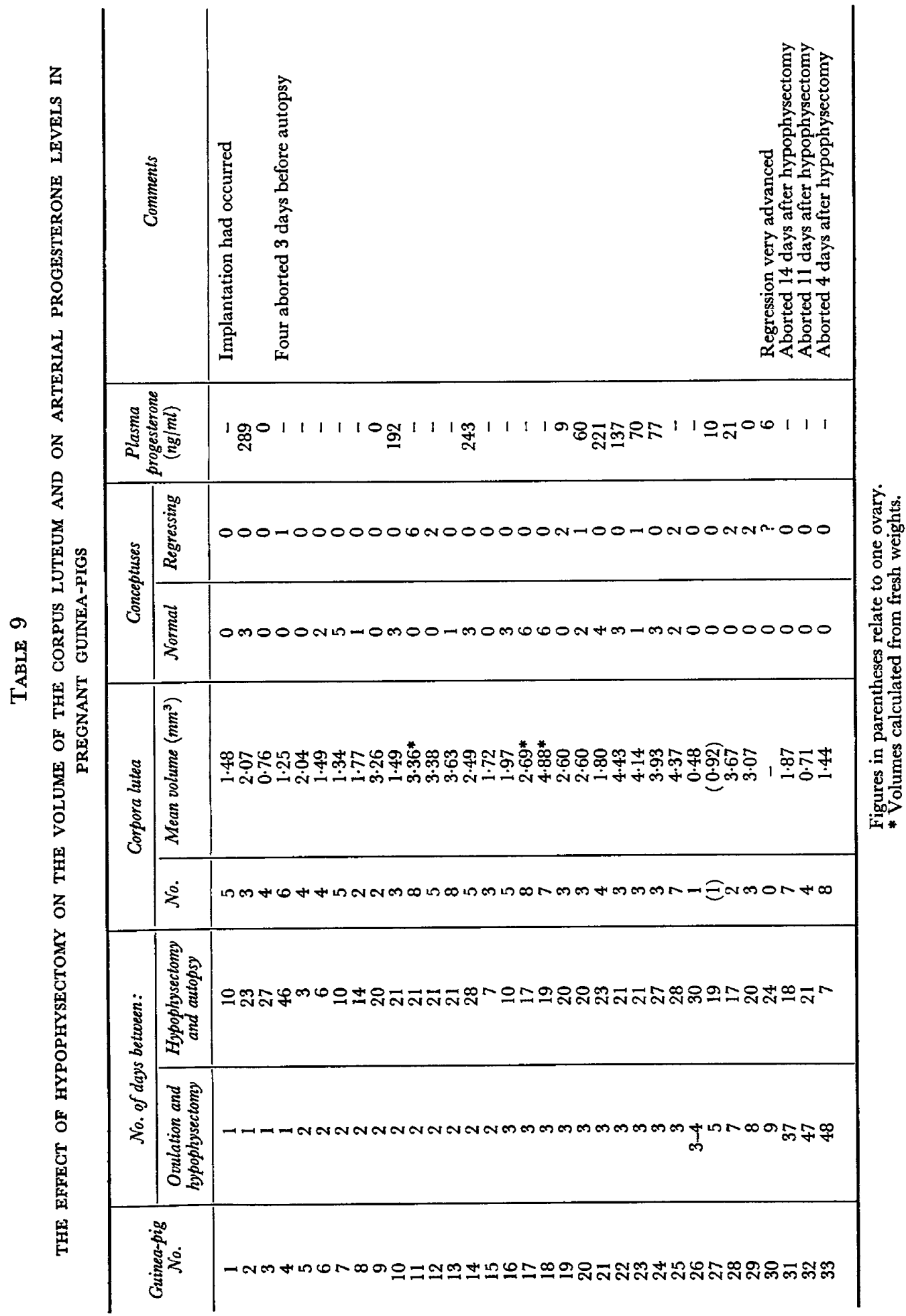


hysterectomy. Corpora lutea were found in nine of the eleven animals; in one animal (No. 291) the mean volume of the corpora lutea was lower than that found in animals at corresponding periods after hypophysectomy alone, but in three others (Nos. 292, 319 and 338) the corpora lutea had grown to a size more nearly comparable to those of animals hysterectomized early in the normal cycle or to those of pregnancy. The arterial progesterone level remained low as in the other groups of non-pregnant guinea-pigs already described.

\section{HISTOCHEMISTRY}

Ovaries of some of the hypophysectomized animals and some of the hysterectomized animals were sectioned in a cryostat and stained with haematoxylin and eosin or oil red $\mathrm{O}$, a lipid stain, or used for the demonstration of $\Delta^{5}-3 \beta$ -

TABLE 10

THE EFFECT OF HYPOPHYSECTOMY AND HYSTERECTOMY ON THE VOLUME OF THE CORPUS LUTEUM AND ON ARTERIAL PROGESTERONE LEVELS IN ELEVEN NON-PREGNANT GUINEA-PIGS

\begin{tabular}{|c|c|c|c|c|c|c|}
\hline \multirow[b]{2}{*}{$\begin{array}{c}\text { Noo. } \\
(\stackrel{H Y G}{ })\end{array}$} & \multicolumn{3}{|c|}{ No. of days between: } & \multicolumn{2}{|c|}{ Corpora lutea } & \multirow{2}{*}{$\begin{array}{c}\text { Plasma } \\
\text { progesterone } \\
(\mathrm{ng} / \mathrm{ml})\end{array}$} \\
\hline & $\begin{array}{l}\text { Ovulation and } \\
\text { hypophy- } \\
\text { sectomy }\end{array}$ & $\begin{array}{l}\text { Hypophy- } \\
\text { sectomy and } \\
\text { hysterectomy }\end{array}$ & $\begin{array}{l}\text { Hyster- } \\
\text { ectomy and } \\
\text { autopsy }\end{array}$ & No. & Volume $\left(\mathrm{mm}^{3}\right)$ & \\
\hline $\begin{array}{l}291 \\
306 \\
292 \\
319 \\
338 \\
389 \\
390 \\
303 \\
388 \\
339 \\
335\end{array}$ & $\begin{array}{l}2 \\
2 \\
2 \\
2 \\
2 \\
2 \\
2 \\
4 \\
4 \\
5 \\
6\end{array}$ & $\begin{array}{r}6 \\
7 \\
7 \\
11 \\
15 \\
21 \\
21 \\
7 \\
23 \\
16 \\
14\end{array}$ & $\begin{array}{l}15 \\
14 \\
15 \\
14 \\
25 \\
23 \\
32 \\
14 \\
23 \\
25 \\
20\end{array}$ & $\begin{array}{l}3 \\
4 \\
5 \\
4 \\
1 \\
0 \\
3 \\
5 \\
0 \\
2 \\
1\end{array}$ & $\begin{array}{c}0.25 \\
2 \cdot 04 \\
4.56 \\
2.98 \\
2 \cdot 82 \\
- \\
1 \cdot 11 \\
1.83 \\
- \\
2 \cdot 18 \\
1.56\end{array}$ & $\begin{array}{c}- \\
- \\
- \\
- \\
\overline{4} \\
5 \\
\overline{10} \\
\overline{8}\end{array}$ \\
\hline
\end{tabular}

hydroxysteroid dehydrogenase by the technique described by Rubin, Deane, Hamilton \& Driks (1963). The presence of this enzyme in luteal tissue is associated with the biosynthesis of progesterone from its precursor $3 \beta$-hydroxypregn-5-en-20-one (pregnenolone). As in intact females, the enzyme was always present in the luteal tissue of hypophysectomized and of hysterectomized guinea-pigs. Sections stained with oil red $\mathrm{O}$ showed a fine dispersion of lipid droplets throughout the cells of the corpus luteum, comparable with the normal corpus luteum before the onset of regression, when the lipid droplets coalesce into large, brightly staining globules.

\section{DISGUSSION}

\section{Luteal and arterial levels of progesterone}

Arterial levels of progesterone were found to be low in guinea-pigs during the normal cycle, after hypophysectomy and after hysterectomy, and in the first 2 weeks of pregnancy. Within the limits of the method employed, a specific and highly sensitive fluorescence assay, these levels were indistinguishable from 
those in ovariectomized animals. Luteal tissue assayed by a similar procedure always contained significant, and in some instances large, amounts of progesterone, with the exception of the corpus luteum in lactation, 12 to 13 days after the post-partum ovulation. The high arterial concentrations of progesterone in pregnancy in guinea-pigs were similar to those found in the coypu, another hystricomorph (Rowlands \& Heap, 1966) and not unlike those reported in man (Zander, 1955; see reviews by Short, 1961, and Fotherby, 1964, for other references). Much lower levels have been found in pregnancy in other animals including ewe, sow, cow, mare (see Short, 1961) and goat (Heap \& Linzell, 1965, 1966) in which the levels are more comparable with those in the oestrous cycle. In the last named species the same fluorescence assay procedure was used as in the present experiments, and significant changes in the arterial progesterone concentrations were recorded during the oestrous cycle. In the guinea-pig, however, no such cyclical changes could be demonstrated. This fact may be related to the measurable amount of progesterone found in this species after ovariectomy. It is possible that this progesterone is of adrenal origin and that its secretion, stimulated by operative stress, masked the small amounts normally present in the oestrous cycle. In the goat it was possible to collect blood for assay from conscious trained animals not subjected to stress at the time of sampling. In this species and in the pig and dog it has been found that the conditions of operative stress may produce a significant rise in the adrenal secretion of progesterone (Heap \& Linzell, 1966; Heap, Holzbauer \& Newport, 1966).

The luteal levels of progesterone in the guinea-pig during the normal cycle, after hysterectomy and in pregnancy were comparable with those previously reported by Rowlands \& Short (1959) and Rowlands (1962) and in general were similar to those found in other species.

It will be noted in the present results that a two- to three-fold rise in luteal progesterone level between the 2nd and 4th week of pregnancy was accompanied by an increase in arterial concentration of at least ten-fold, whereas in the non-pregnant guinea-pig after hypophysectomy or hysterectomy there was a roughly comparable rise in luteal level without any change in the arterial level. This rise in arterial level in pregnancy occurs at a time when the placental progesterone contribution is small and usually inadequate to maintain pregnancy after ovariectomy (see Heap \& Deanesly, 1966, who give other references).

The very low arterial level found during the first 2 weeks after ovulation is evidently adequate for the normal process of implantation on the 7th day post coitum (p.c.), for the demonstration of a decidual reaction which was first shown in this species (Loeb, 1907), and for the delay in ovulation and vaginal opening until about the 16th day after ovulation in the non-pregnant animal. Deanesly (1960) showed that a single injection of only $0.5 \mathrm{mg}$ progesterone allowed implantation to occur in guinea-pigs ovariectomized 2 days p.c. and that implantation occurred at the normal time in animals ovariectomized 3 to 7 days p.c. It has now been found that in ovariectomized, non-pregnant guinea-pigs absorbing up to $1.0 \mathrm{mg} /$ day from subcutaneously implanted tablets of progesterone, the arterial concentration of progesterone is comparable with that in the normal cycle (Deanesly \& Heap, in preparation). 
These data suggest, therefore, that in the guinea-pig very low levels of circulating progesterone, and very small changes in these levels, are associated with significant events in the control of the ovarian cycle. This is in accord with the observation (Rowlands, 1962) that very high doses of oestradiol benzoate were required to induce a vaginal response during the luteal phase of the normal cycle. At that time it was not realized that the high luteal levels of progesterone were not accompanied by high arterial concentrations either in the normal cycle or in hysterectomized animals.

\section{Growth and regression of the corpus luteum}

The results support the view that both luteotrophic and luteolytic factors can be distinguished. After the removal of the pituitary, or the uterus, within about 10 days after ovulation, the corpus luteum persisted for long periods of time. By about 30 days after hypophysectomy the corpus luteum was comparable in size and histological appearance to the corpus luteum of the normal cycle 10 days after ovulation, whereas in hysterectomized females its rate of growth was not affected and the maximum size reached was the same as in pregnancy. Large, persistent corpora lutea have also been found in hysterectomized females after hypophysectomy (Rowlands, 1962) and in hypophysectomized females after hysterectomy (Table 10). The results suggest that pituitary gonadotrophin plays some part in the maintenance of luteal growth in the normal cycle since the number of corpora lutea is decreased and luteal growth is retarded, though not abolished, if hypophysectomy is performed early in the cycle. The increase in size of the corpus luteum after hypophysectomy in unmated guinea-pigs indicates either that the corpus luteum has an inherent capacity to grow which is normally accelerated by a pituitary factor, or that it is still influenced by residual amounts of gonadotrophin.

In the pregnant guinea-pig luteal growth is prolonged either as a result of a positive stimulus from the implantation site or by the elimination of a uterine factor which otherwise inhibits it. The fact that this occurs in the hypophysectomized animal shows that, in either case, the effect is independent of the pituitary gland. If this effect is due to the suppression of a uterine factor it might be expected that hysterectomy of the hypophysectomized animal would have a similar effect on luteal growth. The data shown in Table 10 afford some indication that this may be so in some animals. Thus, of the six animals with corpora lutea after hypophysectomy on the 2nd day after ovulation, those of three were greater than the $95 \%$ fiducial limits given in Table 8 for the volume of corpora lutea after hypophysectomy alone. Deanesly's (1960) results referred to above show that implantation occurs normally on the 7th day after ovulation when ovarian progesterone is withheld from the 3rd day onwards, and our finding that implantation usually occurred at the normal time after hypophysectomy performed on the 3rd day, is in line with her observations. The fact that implantation occurred after hypophysectomy performed on the 2nd day suggests that the surviving corpora lutea continued to secrete progesterone over the critical period. Our observations are most readily interpreted in terms of a positive luteolytic stimulus involving both the pituitary and the uterus. This stimulus is to a large extent eliminated if the pituitary or the 
uterus is removed before the 9th day after ovulation and is reduced if they are removed after the 10 th day.

\section{Luteal function}

It is evident that the control of luteal function in the guinea-pig is complex since the results show that different factors are involved in the growth of the corpus luteum, in the biosynthesis of progesterone and in its secretion as reflected in the circulating concentration of progesterone. The relatively greater discrepancy between luteal and arterial progesterone levels in hysterectomized and hypophysectomized non-pregnant animals, as compared with values in intact females, suggests either that these experimental procedures interfere with progesterone release, or that systemic progesterone metabolism is accelerated. The former hypothesis implies that control of the secretion of progesterone by the ovary may be independent of its synthesis. While direct measurements of ovarian secretion rates of progesterone in this species are not yet available, this hypothesis is supported by the observation that an increase in luteal progesterone levels in the first two weeks of pregnancy is not matched by a corresponding rise in circulating progesterone, and by indirect evidence which suggests that the ovarian secretion of progesterone has declined during the last 2 weeks of pregnancy, when high luteal levels are maintained (Heap \& Deanesly, 1966). This interpretation is also supported by the finding that progesterone concentration was very low in the ovarian vein of nonpregnant guinea-pigs (Neill, Day \& Duncan, 1963). Experiments are in progress with ovariectomized guinea-pigs absorbing progesterone from subcutaneously implanted tablets. It is probable that marked difference in plasma progesterone levels between pregnant and non-pregnant animals, observed in these experiments, is due not only to changes in ovarian secretion rate of progesterone but also to an alteration in the utilization of the hormone in pregnancy.

In the guinea-pig, the growth of the corpus luteum and the luteal synthesis of progesterone appear to depend on a stimulus at the time of ovulation rather than on a continuing secretion of gonadotrophin (Perry \& Rowlands, 1962). The continuing growth of the corpus luteum after the 10th day of pregnancy appears to be related to implantation, which has a similar effect to that of hysterectomy, and the increase in circulating progesterone levels is perhaps associated with the establishment of the allantochorionic placenta.

\section{ACKNOWLEDGMENTS}

We wish to acknowledge the help of Dr Gerald Glough and the skilful technical assistance of Miss Grace Needham and Mrs Valerie Wolton-Garr.

\section{REFERENCES}

DeANesLy, R. (1960) Implantation and early pregnancy in ovariectomized guinea-pigs. F. Reprod. Fert. $1,242$.

DemPSEY, E. W. (1937) Follicular growth rate and ovulation after various experimental procedures in the guinea-pig. Am. F. Physiol. 120, 126.

Fotherby, K. (1964) The biochemistry of progesterone. Vitams Horm. 22, 153.

HEAP, R. B. (1964) A fluorescence assay of progesterone. F. Endocr. 30, 293. 
Heap, R. B. \& Deanesly, R. (1966) Progesterone in systemic blood and placentae of intact and ovariectomized pregnant guinea-pigs. F. Endocr. 34, 417.

Heap, R. B., Holzbauer, M. \& Newport, H. (1966) Adrenal secretion rates of C-19 and C-21 steroids before and after hypophysectomy in the pig and dog. F. Endocr. 36, 159.

Heap, R. B. \& Linzell, J. L. (1965) Plasma progesterone levels in the goat and mammary uptake during pregnancy. F. Physiol., Lond. 180, 10P.

HeAp, R. B. \& LinzelL, J. L. (1966) Arterial concentration, ovarian secretion and mammary uptake of progesterone in goats during the reproductive cycle. F. Endocr. 36, 389.

Heap, R. B., Perry, J. S. \& Rowlands, I. W. (1965) The effect of hypophysectomy on the corpus luteum of the non-pregnant guinea-pig. Acta endocr., Copenh., 50, Suppl. 100, 76.

Loeb, L. (1907) Über die experimentelle Erzeugung von Knoten von Deciduagewebe in dem Uterus des Meerschweinchens nach stattgefundener Gopulation. Zentbl. allg. Path. path. Anat. 18, 563.

LoEB, L. (1932) Some mechanisms in the sexual cycle of the guinea-pig. Aust. F. exp. Biol. 9, 141.

Neill, J. D., Day, B. N. \& Duncan, G. W. (1963) Gas chromatographic determination of progestins in tissue and blood. Steroids, 4, 699.

Perry, J. S. \& Rowlands, I. W. (1962) The effect of hypophysectomy on the ovarian cycle of the guinea-pig. F. Endocr. 25, v.

Perry, J. S. \& Rowlands, I. W. (1963) Hypophysectomy of the immature guinea-pig and the ovarian response to gonadotrophins. $\mathcal{F}$. Reprod. Fert. $6,393$.

Rosenbusch-Weins, D. \& Ponse, K. (1957) Actions rapides et lointaines de l'hypophysectomie chez le cobaye. Revue suisse Zool. 64, 271.

Rowlands, I. W. (1956) The corpus luteum of the guinea-pig. Ciba Fdn Colloq. Ageing, 2, 69.

RowLands, I. W. (1961) Effect of hysterectomy at different stages in the life cycle of the corpus luteum in the guinea-pig. $\mathcal{F}$. Reprod. Fert. $2,341$.

RowLANDs, I. W. (1962) The effect of oestrogens, prolactin and hypophysectomy on the corpora lutea and vagina of hysterectomized guinea-pigs. F. Endocr. 24, 105.

RowLANDS, I. W. \& HEAP, R. B. (1966) Histological observations on the ovary and progesterone levels in the coypu, Myocastor coypus. Symp. Zool. Soc. Lond. 15, 335. Abstract in F. Reprod. Fert. 9, 381.

Rowlands, I. W. \& Short, R. V. (1959) The progesterone content of the guinea-pig corpus luteum during the reproductive cycle and after hysterectomy. F. Endocr. 19, 81 .

Rubin, B. L., Deane, H. W., Hamilton, J. A. \& Driks, E. C. (1963) Changes in $\Delta^{5}$-3 $\beta$-hydroxysteroid dehydrogenase activity in the ovaries of maturing rats. Endocrinology, 72, 924.

Short, R. V. (1958) Progesterone in blood. I. The chemical determination of progesterone in peripheral blood. 7. Endocr. 16, 415.

ShorT, R. V. (1961) Progesterane. Hormones in Blood, chap. 13, p. 379. Eds. C. H. Gray and M. Bacharach. Academic Press, London.

Zander, J. (1955) Progesteron im menschlichem Blut und Geweben. Klin. Wschr. 33, 697. 